folk/ed. 2021; 27(2): 517-535

DOI: $10.22559 /$ folklor.1401

\title{
Bir Etnografi Alegorisi Olarak Karanlığın Sol Eli Romanı
}

\author{
The Left Hand of Darkness as an Allegory of Ethnography
}

\section{Meriç Kükrer*}

$\ddot{O ̈ z}$

$\mathrm{Bu}$ çalışmada bir metin olarak etnografiyi, edebi anlatı bağlamında ele aldım ve Ursula Le Guin'in Karanlığın Sol Eli romanını etnografinin metinsel stratejileri çerçevesinde yorumlamayı hedefledim. Etnografik metnin araştırmacı ile araştırılanın alanda karşılaşma tecrübesini içeren bir anlatı olduğu argümanından yola çıkarak romanda gezegenler arası seyahat eden "erkek" bir elçinin androjenlerle karşılaşma tecrübesi de etnografik metinselleştirme bağlamında yorumlandı. Yapısalcılığın "yazarın ölümü” argümanından hareketle, etnografik ve edebi metinselleştirmenin benzer yapısal düzenlemelerine odaklandım ve Karanlığın Sol Eli metnini etnografinin metinselleştirme stratejilerini kullanan bir alegori olarak okudum. Ethosu yakalamak, gündelik hayatı anlatmak, yoğun betimleme ve etnografik tecrübenin hikâye edilmesi gibi etnografik metinselleştirme stratejileri

Geliş tarihi (Received): 04.09.2020- Kabul tarihi (Accepted): 23.03.2021

* Dr., Süleyman Demirel Üniversitesi Fen-Edebiyat Fakültesi Sosyoloji Bölümü.(Süleyman Demirel University, Faculty of Arts and Sciences, Department of Sociology). merickukrers@gmail.com. ORCID 0000-0001-8069-4564 
romanda da yer almaktadır. Çalışma bu bağlamda şu tartışmalar üzerinden ilerledi: Başlangıçta roman kahramanı Elçi Genli Ai anlatmak üzere olduğu hikâyenin kime ait olduğunu sorgular. $\mathrm{Bu}$ sorgulamayı söyleşimsel nitelikli etnografik metinselleştirmenin bir izdüşümü olarak yorumladım. İkinci olarak Elçi Genli Ai, tıpkı bir etnograf gibi, Gethen halkının yaşam dünyasının keskin bir resmini çizer; gündelik hayatlarını, ritüellerini yoğun bir şekilde betimler ve ethoslarını yakalamaya çalışır. Üzerinde durulan son konu ise yalnızlık duygusu ve bilenbilinen ilişkisindeki dönüşümler bağlamında Genli Ai'nin alan tecrübeleri oldu.

Anahtar sözcükler: alan tecrübesi, alegori, etnografi, etnografik metinselleştirme, metinlerarasılık, metinselleştirme stratejileri

\begin{abstract}
This paper aimed to discuss ethnography as a text within the context of a literary narrative and interpreted a science fiction novel, The Left Hand of Darkness by Ursula Le Guin, with a focus on the textual strategies of ethnography. Based on the argument that the ethnographic text is a narrative that includes the experience of encountering the researcher with the researched in the field, the experience of a "male" messenger traveling interplanetary throughout the novel was interpreted in the context of ethnographic textualization. I focused on the similar structural arrangements of ethnographic and literary textualization, moving from the argument of "the death of the author" of structuralism, and reread The Left Hand of Darkness as an allegory based on the textualization strategies of ethnography. Ethnographic textualization strategies such as capturing the ethos, describing everyday life, thick depiction, and storytelling of ethnographic experience were also included in the novel. Within this context, the study proceeded through the following discussions. At the beginning of the novel, the protagonist questions whose story he is going to talk about. I interpreted this rhetoric as a projection of a dialogical ethnographic textualization. Second, he painted a sharp picture of the living world of the Gethen people, intensely depicting their daily lives and rituals, and pursuing their ethos like an ethnographer. The last topic emphasized was Genly Ai's field experiences within the context of the feeling of loneliness and the transformations in the subject-object relationship.
\end{abstract}

Keywords: allegory, ethnographic textualization, ethnography, field experience, intertextuality, textualization strategies

\title{
Extended summary
}

This article considers ethnography as the experience of the encounter between the researcher and the researched, and the transformation of this experience into a kind of text. It reads the experience, of an encounter with androgens, of a "male" ambassador carrying out interplanetary 
travel in The Left Hand of Darkness, through the nature of ethnographic textualization. This exact point makes it meaningful to establish this study within the framework of the concept of "allegory". Clifford (1986b) points out that ethnography is "allegorical" in form and content. However, he sees ethnography as an allegorical expression of other concepts. Here, in contrast to this view, I read this fiction, which uses the textualization strategies of ethnography while transforming a fictional encounter into a text, as an allegory of ethnography. In other words, I consider literary fiction as an allegory of ethnography and listen to the textualization forms of ethnography.

My approach to the novel stands out from the rest of the literature in that, the reading is not from within the text. Basically, I am looking at how the novel narrates rather than what it says (Chatman, 2009: 10), focusing on similarities between the structural arrangement of textualization in the ethnographic narrative and the novel The Left Hand of Darkness. In this sense, I focus on textualization strategies. I try to make sense of this science fictional ethnography by thinking within the framework of the reasoning of ethnography as a method and a text.

In the novel, the answer to the question "what kind of a social structure could be constructed in a universe where there is no sex such as woman or man, hence there is no social expression of the biological sex?" is narrated through the experiences of the Ambassador who traveled to the planet of Gethen. Ambassador Genly Ai starts his narrative with a rhetorical question: "whose story is this?". By doing so, he draws a narrative framework for the reader too. Although the founding role is in the Ambassador, the narrative of the novel consists of experiences of the Ambassador, views of the native informant, and stories of Gethenian myths. Therefore, it adopts a polyphonic language. Thus, the emerging text in total acquires a dialogical character as well. Considering that the ethnographic text is meant to reveal, with a polyphonic understanding, the potential worlds that are supposed to be common in the minds of both the author and the reader, the question of "whose story is this?" appears as a valuable methodical reasoning tool for ethnography as well.

Arriving on this planet, Genly Ai "conducts his fieldwork" in an anthropological sense. He spends about two years in the environment of the exotic "other", trying to get to know these people whose relationships with their world are different from his own society. During the long journey in the novel, the meaning of everything in Ai's mind will change, and eventually, he will begin to see the world through their eyes. Ai focuses on the "uncertainty" in the biology of the community and sees their rituals, political and daily lives, kinship relations, genderlessness, taboos, languages, myths, and religions as an extension of their bodies. This holistic reading style, here starting from the body, also coincides with the reasoning of ethnography. Ai tries to organize the shapeless space around a concept (or several such concepts) he derives from his field experience, just as ethnographers do. We can see that "androgyny" is used as a reasoning tool to reverse the established social perception and an area of criticism about sex and gender is worked to be established. The attempt to establish this type of criticism also overlaps with the aims of the ethnographic text. The question "in what kind of a world would we live in if we weren't anatomically determined on sex?" on which the novel is built does not allow empirical observation. Based on this methodological impossibility inherent to the fundamental research question, I make sense of what leads the author to an ethnographic textualization. 
As I pursue the ethnographic textualization, I discuss the novel from two different aspects. The first aspect is based on the concepts capturing ethos, everyday life, and thick descriptions which express how Ai, whom I can take as the ethnographer, interprets and explains in a context, what he observed. Within the frame of the ethnographer's experience, the second aspect deals with Ai's encounters in the field. Based on these two aspects, I trace by an intertextual perspective the patterns that constitute ethnographic textualization through a literary text that is far from the scientific claims of ethnography.

\section{Giriş}

İnsan bilimlerinin araştırma yöntemlerinden biri olan etnografiyi, Ursula Le Guin'in Karanlığın Sol Eli romanıyla Gethen gezegeninin androjen sakinleri üzerinden, bir bilim kurgu aracılığıyla tartışmaya açmak ilk bakışta bir oksimoron olarak görülebilir. Oysa genel olarak bilim kurgu metinleri de tıpkı etnografik metinler gibi toplumları, onların siyasetlerini, politik tahayyüllerini, kurumlarını, insan -ya da şeylerin- doğasına dair sorgulamaları, verili olan ve inşa edilen arasında olduğu varsayılan ontolojik ayrımları, yaratılan ötekileri ve tüm bunlarla ilişkileri yazınına konu eder. Bunu yaparken de insanı, bilimi, teknolojiyi ve insan dışı varlıkları; yapay zekâları, robotları, sayborgları, süper kahramanları, uzaylıları, canavarları, zombileri, alternatif tarihleri, yok oluşları, paralel evrenleri, siber ortamları, alternatif anatomileri ve toplumları kullanır. Bu bağlamıyla da bilim kurgunun, gerçekliği esnetme ve yaşam dünyasını sorgulama yöntemlerini genişletme açısından hayli renkli bir alan sunduğunu söyleyebiliriz. Ağırlıklı olarak, kurumsallaşmış bir disiplin içinden yazılması beklenen etnografi ise, dili bilimsel protokolüne içkin ve sınırları da kendi gerçekliğinin içerisinde çizilmiş metinler üretir. Ancak her iki metin türü de en nihayetinde "bir başkasının" farklı türden pratiklerini göstermek suretiyle okurlarının ön kabullerini, inançlarını, toplumsal yargılarını, beklentilerini paranteze aldırarak yerleşik hükümleri zayıflatma ve eleştirel bir bakışa yönelme eğilimindedir.

Öte yandan en temelde etnografiyi, "araştırmacı ile araştırılanın karşılaşma tecrübesine" ve "bu tecrübenin bir tür metne dönüşmesine" indirgediğimizde, bir başka ifadeyle etnografi ile ilgili fikirlerimizi yalınlaştırdığımızda, düşünce koordinatlarımızla bir miktar oynamamız mümkün olacaktır. "İnsan” ve "insan dışı varlıklar" arasında, Foucault'da (2006) "akıl” ile "akıl dışı” tanımlamaları aracılığıyla kurulan, birini bir diğerinin içinden anlamlandırma ya da tanımlama ilişkisinden esinlenerek bir okuma yapmak elbette düşünülebilir. Oysa burada yapmak istediğim şey, Gethen gezegeninin alternatif anatomiye sahip varlıkları üzerinden bir felsefi antropoloji tartışmasına girişmek değil, Gethen'e dünyadan giden bir elçinin, androjenlerle karşılaşma tecrübesinin ifade ediliş biçimini, etnografik metinselleştirmenin doğası içerisinden okumaya çalışmaktır. Tam da bu noktada çalışmanın "alegori” kavramı çerçevesinde kurulması, anlamını bulur. Clifford (1986b) etnografinin, biçim ve içerik bakımından "alegorikliğine" dikkat çeker. Alegori kavramı geniş manada, bir yaşam tecrübesinin, daha etkileyici olabilmesi için çarpıcı bir metaforik anlatım yoluyla ifade edilmesi anlamına gelir. Clifford etnografiyi, bir tecrübenin metne dökülmesinden hareketle 
ele alır. Bu çerçevede örneğin Marjorie Shostak'ın, Afrika kabilelerinden birine mensup olan bir kadının hayatını, kendi tecrübelerini ve soyutlamalarını da peşi sıra ekleme vasıtasıyla metinleştirerek anlattı̆̆ Nisa / Bir Kung Kadınının Yaşamı Ve Sözleri (1981) etnografisi Clifford'a göre, kadınlığın feminist bir alegorisidir. Yine benzer biçimde, Sudan'da düzenli anarşi halindeki bir kabileyi anlatan E. Evans-Pritchard'ın The Nuer (1940) etnografisini de Anglosakson halk demokrasisi modelini sorgulatan politik bir alegori olarak okur. Bu çalışmada ise etnografileri başka kavramların alegorik anlatımı olarak gören bakışın tersine, kurmaca bir karşılaşmayı metne dönüştürürken etnografinin metinselleştirme stratejilerini kullanan bir kurgu, etnografinin alegorisi olarak okunuyor. Bir başka deyişle, alegori kavramından hareketle etnografinin edebî bir performansa dönüştüğünü söyleyen Clifford'ın aksine, edebî bir kurgu etnografi alegorisi olarak okunup etnografinin metinselleştirme biçimlerine kulak veriliyor.

Roman "kadın ya da erkek gibi kesin bir cinsiyetin bulunmadığı, dolayısıyla da biyolojik cinsiyetin toplumsal ifadesinin olmadığı bir evrende nasıl bir sosyal yapı inşa edilebilirdi” sorusunun cevabını, Gethen gezegenine giden elçinin tecrübeleri üzerinden anlatır. Tam da bu yabancılık tecrübesinin ifadesi bağlamında etnografik metin ile örtüştürerek "etnografi alegorisi" tanımlamasıyla yeniden okumaya davet ettiğim Karanlı̆̆ın Sol Eli, literatürde farklı bağlamlarıyla hayli tartışmaya konu olmuş bir romandır. En fazla ihtilaf yaratan, zaten romanın da üzerine inşa edildiği, toplumsal cinsiyet meselesidir. Bu bağlamda temel olarak "androjen" kavramı eleştirilir (Fayad, 1997). Androjen, Aristophanes'in (Platon, 2012: 190) anlattığı yaratılış hikâyesinde, Zeus tarafından ikiye bölünmeden önce, kadın ve erkek cinsini içine alan bir "bütün insan"dır. Tanrılara isyan ettiği için ikiye bölünüp, hayatı boyunca bölündüğü parçasını aramakla cezalandırılan bu androjen yarısının, yani insanın arayışı, hangi cinsten kesildiğine göre değişiklik gösterecek; farklı cinsten kesilmişler karşı cinsi, kendi cinsinden kesilenlerse kendi cinsini arayacaktır. Ancak bu mitolojik hikâyedeki tüm bu eşleşmelerin içerisinde erkekten kesilmiş erkeğin, erkek yarısını bularak bütünleşmesi, muhtevasında "en çok erkekliğgi” barındıracağından, nihai tamamlanmışlık hali olarak gösterilir. Buradan hareketle androjen kavramına cinsiyetler arası bir hiyerarşinin içkin olduğu söylenebilir. Feministler tarafından da en sert eleştirilerin yapıldı̆̆ Guin'e "cinsiyetçi”" demeye varacak kadar ileri giden tartışmaların odak noktası, romanda androjenlik kavramı çerçevesinde gelişen ve bu içkin anlamı onayladığı düşünülen olay örgüsüdür. Fakat bazı yazarlar da bu ithamlarla Le Guin'e haksızlık edildiğini düşünürler ve romanı, toplumsal cinsiyet kimliklerine meydan okuma konusunda başarılı bir metin olarak değerlendirirler (Barrow and Barrow, 1987). Kimi başka çalışmalarda ise Gethen gezegeninin dinleriyle Hristiyanlık, Budizm, Taoizm arasında kurulan bağlantılar; uyum, zıtlık, düalizm kavramları çerçevesinde tartışılır (Lake, 1981). Kimisinde de özellikle Lévi-Strauss'a gönderme yaparak, romandaki mitler, ensest tabusu ve akrabalık ilişkileri, "mübadele" kavramı çerçevesinde incelenir (Walker, 1979). Bir başkasında ise Gethen'e gelen elçi ve onu gönderen Ekumen üzerinden kolonyalizm tartışmaları yapılır (Pearson, 2007). Üye gezegenler arasındaki her türden alışverişin koordinasyonunu sağlayan "Ekumen”, emperyal bir oluşum ve birliğe katılmaya ikna etmek için Gethen'e gönderdiği "elçi” ise antropolog 
olarak değerlendirilir. Bu çerçevede de elçinin Ekumen'den Gethen'e ettiği seyahat, klasik antropologların "ilkel olanın egzotik mekânına" gidişiyle benzetilerek romanda, kolonyal ilişkiler çerçevesinde antropolojik bağlam ön plana çıkartılır. Ancak burada romanın ele alınış biçimi, tüm bu literatürde yapılan çalışmalardan farklı bir yerde durmaktadır. Öncelikle yukarıda bahsi geçtiği şekliyle metnin içinden yapılan bir okuma değildir. Diğer bir ifadeyle temelde, romanın "ne" anlattı̆̆ından ziyade "nasıl" anlattığına bakıyor (Chatman, 2009: 10), etnografik anlatıyla Karanlığın Sol Eli romanı arasındaki benzer metinselleştirmenin yapısal düzenlemesine odaklanıyorum. Bu anlamda yazarın niyetlerinin, zihninin ve metnin içindeki olayların dışına çıkarak, metinselleştirme stratejilerini merkeze alıyorum. Yazarın bu kurgusunda neden etnografik bir metinselleştirmeyi "taklit" etmeye ihtiyaç duymuş olabileceğinin cevabını ararken, ebeveynlerinin antropolog olması gibi kolaycı bir açıklamadan hareket etmiyor ve yazarın kendisine işaret eden bir bağlam kurmuyorum. Daha net bir ifadeyle, yapısalcıların dile getirdiği gibi "yazarı öldürerek" bir metin okumasına girişiyorum (Barthes, 2013 ve Foucault, 1981). Yazılan bu bilim kurgusal etnografiyi, hem yöntem hem de metin olarak etnografinin akıl yürütmesi içinden düşünerek anlamlandırmaya çalışıyorum.

$\mathrm{Bu}$ bağlamda bir etnografi alegorisi olarak yeniden tanımladığım Karanlı̆̆ın Sol Eli romanını; ethosu yakalamak, gündelik hayat ve yoğun betimlemeler ile etnografin tecrübeleri eksenlerinde ele alacağım ancak öncelikle romanın, etnografi ile nasıl birlikte düşünülebileceğini tartışmaya açacağım.

\section{Karanlı̆̆ın Sol Eli’ni etnografi ile düşünmek}

Romanda olay örgüsü başlamadan önce hikâyenin başkahramanı elçi, okuyucuya tecrübesini anlatma yöntemi açıklar; "raporumu bir hikâye anlatırmış gibi vereceğim" ve ardından şöyle devam eder:

"Bu hikâye sırf benim hikâyem değil, anlatan da bir tek ben değilim. Doğrusu kimin hikâyesi olduğundan bile emin değilim; sizler daha iyi takdir edersiniz. Ama baştan aşağı tek bir hikâye. Kimi zaman ses değiştikçe olgular değişmiş gibi gözükürse siz en hoşunuza giden olguyu seçiverirsiniz olur biter; yine de hiçbiri yalan değil bunların ve baştan aşağı tek bir hikâye" (Le Guin, 2010: 15-16).

Elçi, Genli Ai, “bu hikâye kimin hikâyesidir?” gibi retorik bir sorunun cevabını verirken okuyucu için de bir anlatı iskeleti çizer. Anlatıdaki seslerin değişeceğini ve perspektif değiştikçe de olguların farklılaşacağını, dolayısıyla dile getirilen tecrübenin anlatıcısının da kesin bir şekilde belli olamayacağını peşinen bildirir. Hikâyelerin çokluğuna ve aidiyetlerindeki muğlaklığa rağmen yaşanan anın tekliğine işaret eden Ai, kişilerin "beğendikleri” olgularla hikâyesini yaratacağını söyler. Bu retorik soru hikâye etmeye dair bir çözümlemeye de işaret eder; gerçek ile mitin, düz anlam ile mecazın, birlik ile çokluğun, çeşitlilik ile bütünlüğün iç içe geçeğini ima ederek esasen evreni deneyimlemeye dair epistemolojik bir açıklamada bulunur. Roman çoğunlukla, toplumsal cinsiyetini içselleştirmiş bir erkek olan Terralı 
(dünyalı) elçi Genli Ai’nin ağzından aktarılır. Kitap yirmi ana bölümden ve sonunda da Gethenlilerin zaman sınıflamasını anlatan "Gethen Takvimi ve Saati” kısmından oluşur. On bölüm, Genli Ai’nin günlük şeklinde yazılmış raporlarıdır. Dört bölüm, Ai’nin Gethenli informant $1^{1}$ Estraven'in anlatımıdır. Geriye kalan altı bölümün beşi Gethen efsanelerinden; bir tanesi de Ai'den önce Gethen'e gidip örtük bir çalışma yaparak Gethenliler hakkında bilgi toplayan bir araştırmacının raporundan oluşur. Anlaşılacağı gibi romanın anlatı yapısı tecrübe temellidir. Kurucu rol Ai'de olsa da zaman zaman informantının sesiyle yerli zihnin, bazen de mitler aracılığıyla kolektif hafızanın, yani topluluğun kendisini hikâyeleştirme şeklinin sesini duyarız. Ai’nin yanı sıra kendi metinleriyle hikâyeye katılan diğer unsurlar da anlatıya çok sesli bir dil kazandırırlar. Böylelikle toplamda ortaya çıkan metin de "diyalojik" (Bakhtin, 1982) bir karakter edinir. Nitekim hem “dışarıdan” hem "içeriden” hem de efsaneler aracılığıyla kolektif hafızadan gelen bilgilerle tarafların birbirlerini nasıl gördüklerine, hayatı algılama ve anlamlandırma biçimlerine şahit oluruz.

Etnografik metnin de çok sesli bir anlayışla hem yazarın hem okurun zihninde ortak olduğu varsayılan potansiyel dünyaları, "anımsatarak” (Scholte, 1987: 41) açığa çıkarmak olduğu kabul edildiğinde, "anlatılan bu hikâye kimin hikâyesidir?” sorusu etnografi için de değerli bir yöntemsel akıl yürütme aparatı olarak belirir. Bir geçmişe, hafızaya ve belli bir bakışa sahip kişi olarak etnograf, metninde kendi hikâyesini mi, içine girdiği topluluğun hikâyesini mi yoksa tecrübenin kendine mahsus sınırlarında ikisinin iç içe geçerek yarattığı bir başka hikâyeyi mi anlatır? Bu soruları düşündüğümüzde, etnografın alandaki konumu, işlevi ve ortaya çıkan metnin bilimselliği, tartışmaların odak noktaları olarak karşımıza çıkar. Ve temelde bunlar üzerine üretilen bütün argümanlar da pozitivizm ile beşerî bilimler ayrımına bağlanarak anlamını bulur. İlkin bir takım matematiksel verilerle topluluğun rakamsal betimlemesini ve analizini yapmayan, bizatihi güçlü gözlem ve anlatım yeteneğiyle derdini yazıyla aktaran -ya da bu şekilde olması beklenen- etnografinin, doğa bilimlerinden belirgin bir biçime ayrılan retoriği hemen göze çarpar. Etnografi hem alan çalışması pratiği hem de sonunda ortaya çıkan metnin retoriği bakımından pozitivist paradigmanın bilimsel ön kabullerine uymayan bir karaktere sahiptir. Bizatihi bir oluşun, bir pratiğin içerisinde yer alan etnograf hakikati, dışsal ve gayri şahsi olarak göremez, "gerçek" etnografın tecrübesinde vücut bulur. Bu tecrübenin ifadesi olan etnografik metin gayri resmi, metaforik ve çok anlamlı bir dil ile kendini inşa ederken, dilin bütün imkânlarından yararlanır: keşfeder, yorumlar, anlar, anlamlandırır. Topluluğun kesin yasalarını saptamak yerine tecrübenin dönüştürücü etkisine kendini ve metnini açan etnograf, perspektifinin "konumlanmış bakışını" da bilgi nesnesi olarak ortaya koyar (Clifford, 1896a).

Öte yandan egzotik hikâyeler, tarihsel olarak genellikle "yabanıllık", "ilkellik" bağlamına yerleştirilir. Romanda da kurgusal olarak, egzotik bir kültürü tanımanın ve metne dökmenin, klasik etnografilerden alışılagelmiş formunu görürüz. Bu bağlamda evrimci bir bakış da hemen göze çarpar. Hem Terra-Gethen arasında hem de Gethen'in iki ülkesi Karhide-Orgoreyn arasında tarihsel olarak lineer bir ilişki kurulur. Ai özellikle de Orgoreyn'e baktığında, sanki atalarına bakıyor gibi hissetmekte ve Terra'nın eski halini görmektedir. $\mathrm{Bu}$ da uzunca bir süre zihinlerde etnograf için uyanan, atalarının nasıl yaşadığını öğrenme 
amacıyla "ilkel kabilelerle" vakit geçiren, "zaman tüneli içindeki naif araştırmacı" imgesiyle de örtüşmektedir. Seksen üç gezegenin birleşerek oluşturduğu Ekumen adındaki birlik, birliğe katılmaya ikna etmesi için Ai'yi bu gezegene gönderir. Elçi kültürün, teknolojinin, rasyonelliğin mekânı Terra'dan; ilkelin, doğanın, duygunun hüküm sürdüğü Gethen'e gelir. Teknolojiye sahip olduğundan kendi dışındakilerle de iletişim kurma imkânı olan taraf, naturasının doğrudan ifadesini yaşayan doğayı fethetmeye gelmiştir. Diğer taraftan Lake (1981: 156), Karanlı̆̆ın Sol Eli'nde Gethen'in iki ülkesi için karşıt imgelerin nasıl kurulduğunu inceler. Romanda bu iki ülke, en temelde sıcak ve soğuk ile ilişkilendirilir. Bunların peşi sıra da yine zıt bir biçimde rasyonalizm ve sezgi, kesin bilgi ve cehalet, ölüm ve yaşam sembolleştirmeleri gelir. Lake tüm metinde bu tip bir dikotomik akıl yürütmenin yakalanabileceğini ifade eder. Lake'in çalışmasında roman içindeki iki ülkenin birbirine göre konumlandırılışı konu edilmiş olsa da aynı bağlantılar hem Terra'nın Gethen ile hem de etnografın nesnesi ile kurduğu ilişkinin izdüşümü gibidir. "Medeni” ile "yerli” arasındaki karşılaşma, klasik antropolojinin nesnesiyle kurduğu ilişkide işleyen düalistik düşünceyle anlam kazanır. Bu bağlamıyla da yukarıda da ifade edildiği gibi elçinin bu mekânsal hareketliliği, klasik antropologların seyahati gibi de okunabilir. Ai bu gezegene gelerek antropolojik manada “alana çıkar”. Egzotik “ötekinin” mekânında yaklaşık iki yıl vakit geçirir, dünyaları ile kurdukları ilişkiler kendi toplumundan farklı olan bu insanları tanımaya çalışır. Özellikle Gethenli arkadaşı Estraven'e, etnografik jargonla ifade edersek “informantına”, sürekli sorular sorarak onların yaşam dünyasını "anlamaya" çalışır. Ancak bütün çabasına rağmen hep bir şeyleri kaçırdığına dair bir hissiyatı vardır. Yanlış bir şeyler demeye çekindiğinden Gethen insanları ile bir araya geldiğinde genelde havadan sudan konuşmayı tercih eder çünkü ona, söylediği her şeyin çift anlamı varmış gibi görünür. Gethenlilerin kendisine, onları yargıladığından haberdarlarmış gibi baktıklarını düşünür ve buna dair de içinde daima bir sıkıntı vardır. Çoğu zaman bir yalnızlık duygusuna gark olarak, neyin ne anlama geldiğini çözemediği bir toplumda, yüzlerini okuyamadığg "tuhaf” insanlarla birlikte yaşamak zorunda kalır. Elçinin bu yabancılıktan ileri gelen yalnızlık hissiyatı, informantının kendisini terk etmesiyle tetiklenen ve gezegende kendi yolunu bulmaya çalışırken gelişen olaylar neticesinde sona erecektir. Bu yolculukta Ai'nin zihnindeki her şeyin yeri, anlamı değişecek ve nihayetinde dünyayı onların gözünden görmeye başlayacaktır.

Üzerinde durulması gereken bir başka konu da Le Guin'in romanı yazma yıllarıyla Malinowski’nin günlüklerinin yayımlanması arasındaki zamansal denk geliştir. Malinowski’nin (1989) ölümünden yaklaşık 25 yıl sonra, karısının tesadüfen bulduğu alan günlükleri 1967'de basılır. Bu metin, araştırmacının alandaki konumu ve hissiyatı bakımından bir hayli dikkate değerdir. Yerlileri pis ve mide bulandırıcı bulduğunu günlüklerinde ifade eden Malinowski, bu nahoş tarifleriyle, sosyal antropoloji disiplininin tarihi içinde genellikle egzotik uzamlarda yaşadığı varsayılan, medeniyet ile "bozulmamış" yerli toplulukların temsilini ve aralarına katılmış yalnız etnograf tahayyülünü sarsacaktır. Sansasyonel bir etki yaratan bu günlükten yaklaşık iki yıl sonra, 1969 yılında ise Karanlı̆̆ın Sol Eli ilk baskısını yapar. Ai de tıpkı bir etnograf gibi gezegene geldiği günden itibaren kendisine günlük notlar tutar, ancak bir antropoloğun günlüğünü ifşa edememesinin aksine burada Ai'nin yerliler 
arasında yaşarken ne düşünüp ne hissettiğini okuyucu ile paylaşır.

Romanın bir parçası, Ai'den önce Gethen'de örtük gözlemler yapan araştırmacı tarafından yazılan "Cinsiyet Sorunu" isimli bölümdür. Burada Gethenlilerin anatomileri, cinselliklerini nasıl yaşadıkları ve buradan hareketle de toplumsal yapılarını nasıl organize ettikleri hakkındaki yorumlar, altı sayfalık etnografik nitelikli alan notunda anlatılır. Gethenlilerin bedenleri yirmi altı ile yirmi sekiz gün arasında değişen bir hormonal çevrime sahiptir ve zamanlarının beşte dördünü "sommer" adı verilen bir dönemde geçirirler. Bu periyotta kişiler tamamen androjendir, yani hiçbir cinsel itki duymazlar. Ancak bu, cinsel olarak pasifliğe değil bir tür "gizil olmaya", potansiyel olarak var olmaya işaret ettiğinden daha çok ergenliğe benzer. Yaşamlarının beşte birinde ise androjenliğin bozularak cinsiyet açısından belirginleşmeye başladıkları "kemmer" evresindedirler. Hormonlar faaliyete geçse de kemmer evresine girer girmez cinsiyet hemen tayin edilmez, cinsiyetin belirgin olabilmesi ve birleşme yetisi kazanılabilmesi için yine kemmerde olan bir partnere ihtiyaç duyulur. Ortak girilen bu eşleşme sürecinin sonunda, o anki hormon durumlarına ve birbirlerine olan konumlarına göre cinsiyetleri de belirlenmiş olur. Bu biyolojik ve sosyal etkinlik kendileri için de bilinmez bir süreçtir, kişilerin girecekleri cinsiyeti tayin etme iradeleri bulunmaz. Kemmer bitiminin akabinde ise yine sommer evresi başlar. Kemmer-sommer döngüsü fenomeninin Gethenlileri yönettiğini gözlemleyen araştırmacı, "toplum yapıları, sanayi, tarım ve ticaretin yürütülüşş şekli, yerleşim birimlerinin boyutu, hikâyelerinin konuları, her şey somer-kemmer çevrimine uygun biçimlenmiş (...) Gethen toplumu gündelik işleyişi ve sürekliliği içinde cinsellikten yoksun bir toplum" (Le Guin, 2010: 87) diyerek alan notunda birtakım yorumlarda bulunur. Geniş zaman kullanarak, zamanlar ve kişiler üstü bir dille tıpkı etnograf gibi nesnesini tasvir eden araştırmacı, sonrasında da cinsiyetle kurulan varlık/yokluk ilişkisini açığa çıkarır. Örneğin toplumda işler kadın ya da erkek işi olarak sınıflanmamıştır, herkesin her şeyi becerebildiği bir toplumdur. Araştırmacının "yokluğuyla” dikkatini çeken şeyler ise şöyle sıralanabilir; hiç kimsenin çocuk bakımına katı bir biçimde bağlanmaması, Oidipus kompleksinin olmaması, gayri iradî cinsel ilişkinin olmaması, insanların koruyan/ kollanan, hükmeden/hükmedilen, sahip olan/sahip olunan, aktif/pasif olarak düalist bir eğilimle bölünmemişliği, cinselliğin belirli günlere hapsedilmiş olmasından dolayı gündelik hayatta flörtün olmaması ve bu yüzden de insanların alışageldiği davranış kalıplarının olmaması ve savaşın olmaması. Tüm bunlar metinde, düalist bir cinsiyetin olmamasının toplumsal tezahürleri olarak sunulur.

Ai de diğer araştırmacı gibi, içine girdiği topluluğun biyolojisindeki "müphemliği” odağına alarak ritüellerini, siyasal yaşamlarını, gündelik hayatlarını, akrabalık ilişkilerini, toplumsal cinsiyetsizliklerini, tabularını, dillerini, mitlerini, dinlerini, bedenlerinin bir uzantısı olarak görür. Bedenden hareket eden bu holistik okuma biçimi etnografinin akıl yürütmesiyle de örtüşür. Elçi, tıpkı etnografların yaptığı gibi, biçimsiz uzayı alan tecrübesinden elde ettiği bir (ya da birkaç) kavram etrafında düzenlemeye çalışır. Olan biteni, bu kavramı içeren kategorilerle anlamlandırır. Bir başka ifadeyle bu kavramın etrafında şeylere anlam yükler. "Gözlem yapmak" ile ilişkili olarak görülebilecek bu durum, gözlenen ve dâhil olunan hayatın bir bütünlük arz etmesinden kaynaklanır. Bu bütünlük hali de metin dolayımıyla taklit edilerek 
yeniden üretilir. Bu tamlık bir çeşit düzenlilik göstergesi olarak da okunabilir. Çünkü etnograf baktığı yerden, bir şeyleri kavrarken temel bir ayrımla ilişki kuruyorsa gördüklerinde içsel bir uyum yakalaması da kaçınılmazdır. Bu romanda ise çözümleme yapmak için ayağın basıldığı yer, kurucu ilke "android beden"dir. Kesin cinsiyet olmamasıyla bizatihi şekillenen yaşam dünyasındaki farklılıklar, anlamlandırmanın temelini oluşturmak için romanda araştırmacının karşısına çıkan en büyük farktır. Bir nevi her yerde cinsiyetsizliğin iz düşümünü görmektedir. Dolayısıyla bu metne bir başka açıdan bakıldığında, "müphemliğin alegorisi” olarak da okunabilir. Romanda cinsiyet ve toplumsal cinsiyet konusunda bir eleştiri alanı kurulmaya çalışıldığından yerleşik toplumsal algıyı ters yüz etmek için “androjenliğin” bir akıl yürütme aracı olarak kullanıldığını görüyoruz. "Gerçekten ters yüz edebildi mi yoksa söz konusu toplumsal hükümleri daha da mı güçlendirdi” hususundaki tartışmalar, bu yazının kapsamı dışındadır. Anlatı çözümlemesinde işaret edildiği biçimde "bir şeyi anlatmanın yolu" olarak "söylem" kavramından hareketle burada, metnin "söylemi”nin etnografik anlatıyla ne denli örtüştüğü çözümleniyor.

Alan çalışmasını yaparken, etnografın kendi anlamlandırmalarını tamamen paranteze alması mümkün olmasa da şahit olduklarını kendi kavramsal çerçevesi dâhilinde yorumlamaktan da imtina eder ve birlikte olduğu insanların anlam dünyasına olağanca erişmeye çalışır. Böylece etnograf, çalışması sırasında dünyayı farklı biçimlerde anlamlandırmayı da öğrenir. Zira dâhil olduğu toplulukların kavramsallaştırmaları içinde ve onlar aracılığıyla alanda var olabilir. Sosyal antropoloji disiplini içerisinde bir yandan da hayli tartışmalı bir ilke olan "kültürel görecelilik", toplulukların anlamlandırma biçimlerinin ve yaşam dünyalarının farklılığı üzerinden, başka gerçekliklere, dünya-içinde-olma ve dünya ile-olma (Heidegger, 2011) yollarının çeşitliliğine işaret eden bir kavramdır. Bu bakışın içinden üretilen etnografik metinler de pozitivist sosyal bilim paradigmasının var olanı yeniden üretme ve onaylama hevesine mesafeli durduğu için basmakalıp fikirleri sorgulama imkânı tanır; var olan kanıyı eleştirel bir gözle yeniden düşünmeye davet eder, başka türden gerçekliklere kendini açarken harici deneyimleri de aşina kılar. Ancak romanın, üzerine inşa edildiği, "anatomik olarak kesin cinsiyetlendirilmemiş olsaydık nasıl bir dünyada yaşardık?” sorusu, ampirik gözleme izin vermeyen bir yapıya sahiptir. Yazarı etnografik bir metinselleştirmeye yönlendirenin ne olduğunu, tam da temel sorunun içinde barındırdığı bu yöntemsel imkânsızlıktan hareketle anlamlandırabiliriz. Sorulan sorunun antropolojik karakteri şüphesiz ortada ancak, etnografik bir tecrübe yaşanabilecek bir konu da değil. Dolayısıyla bu koşullarda mümkün olabilecek etkili cevaplardan biri kurgusal gözlemler kullanılarak etnografik metinselleştirmenin “taklidi” olacak şekilde kurmaca bir etnografi yazılmasıdır. Her birinin arasında lineer değil döngüsel bir bağ olduğunu göz önünde bulundurarak etnografide sorudan metne giden yolu kabaca şu şekilde takip edilebiliriz: Soru sorulur, alana çıkılır, sorunsal kurulur ve metin inşa edilir. Romanda ise soru ile metin arasında tecrübî olarak doldurulması mümkün olmayan boşluğun, kurgusal bir etnografik alan araştırmasıyla tamamlandığını görürüz. Ai, pratiklerine dâhil olduğu toplumda bir etnografin baktığı yerlere; ritüellere, siyasal yaşama, gündelik hayata, akrabalık ilişkilerine, toplumsal cinsiyete, tabulara, dile, mitlere, dine etnografin baktığı gibi bakar ve bunları tecrübenin diliyle metinleştirir. Nihayetinde de genel kanıyı 
sorgulamaya yönelik bir metinsel girişimde bulunmak suretiyle Karanlığın Sol Eli romanı, etnografinin niyetleriyle örtüşür.

Roman yukarıda da bahsedildiği üzere din, ritüel, tabu gibi temalar etrafinda anlatılsa da burada etnografik metinselleştirme takip edildiği için ethosu yakalamak, gündelik hayat ve yoğun betimlemeler ile etnografin tecrübesi kategorileri altında metni ele alacağım.

\section{Ethosu yakalamak, gündelik hayat ve yoğun betimlemeler}

Etnografik yöntemi kullanan araştırmacı, deneylerin, anketlerin aksine kendisi tarafından doğrudan yapılandırılmamış bir ortama, açık ya da örtük bir biçimde dâhil olarak yani insan pratiklerine doğrudan katılarak ve onları tecrübe ederek kurulan bir çalışmanın içerisindedir. Böylesi bir çalışma da anlamların pratikte, davranışta ve eylemde yakalanabileceğine dair bir ön kabulü içinde barındırır. Ancak Geertz (2010: 30) bu hususta bir şerh düşerek ilk elden bilgiyi araştırmacının yakalayamayacağını söyler. Çünkü bu türden bir bilgi doğrudan üreticisine yani topluluğa aittir, araştırmacı etnografi ile yalnızca yorumlanmış bir dünyanın yorumunu yapabilir. Dolayısıyla yapılan iş, "işaret eden" ile "işaret edilen" in ilişkisi bağlamında kültürün semiyotiği olacaktır. Tecrübeyi düzenleyen unsurları insani deneyimin ön koşulu olarak gören Geertz'e göre (2010: 153) etnografi, toplulukların varoluşlarına yükledikleri anlamların biriktirildiği yerler olan simgeleri yakalamalıdır. Etnograf da bu bağlamda, Geertz'in Gilbert Ryle'dan alarak geliştirdiği "yoğun betimleme” kavramının doğasına uygun olarak gündelik hayatı anlatıya dönüştürür. Yoğun betimleme ile yapılan şey insanların tecrübelerini ve anlamlandırmalarını, oluş içindeyken, o an teşekkül ettiği haliyle, yorumlar üzerine kurulan yorumlar aracılığıyla kurgulayarak anlatısallaştırmaktır.

Öte yandan temelinde "dünyayı kurma biçimlerine" ilişkin yürütülen etnografik çalışma için yapıp etmelerle ifadesini bulan bir "anlam" tanımından yola çıkıldığında bu anlamların keşfi için de söz konusu pratiğe, gündelik hayata bir yerinden dâhil olmanın gerekliliği daha anlaşılır olacaktır. Bir oluş içindeyken etnografın gördüğü, yorumladığı, idrâk ettiği şeylerden belki de en önemlileri topluluğun “ethos”u ve “dünya görüşü”dür. Geertz’e göre ethos, topluluk yaşamının karakteri, tonu ve niteliğine işaret ederken, dünya görüşü ise olan bitenin insanlara nasıl göründüğü ile ilgili bir kavramsallaştırmadır. Dahası bu ikisi arasındaki ilişki de Ricoeur'ün izinden giden Geertz'e göre döngüseldir, bir başka şekilde söyleyecek olursak hem ethos ve dünya görüşü hem de etnografi birbiri üzerine binen yorumların yorumlarıdır.

Özetle etnografi, insanların dünya ile ilişki kurma biçimlerini, farklı yaşam dünyalarını, insanın muhtelif varoluş tezahürlerini ortaya koyarak “insanın neliği” konusunda entelektüel bir çabaya girişir ve bir metin vasıtasıyla da kendi varlığını tamamlar. Esas önemi de, “insanın varlık alanlarını” imlemek suretiyle bir başka gerçekliğin olasılıklarını gözler önüne sererek düşünce koordinatlarımızla oynamasında yatar. Benzer bir girişimi Karanlığın Sol Eli romanında da görürüz. Ai, Gethen insanlarının yaşam dünyasının keskin bir resmini çizmeye çalışır; gündelik hayatlarını tasvir eder, ritüellerini yoğun bir şekilde betimler ve ethoslarını yakalar. Romanda ethos konusunda iki önemli kavram olarak "şifgretor" ve "nusuth" karşımıza çıkar. Şifgretor kelimesi, Karhidece "gölge" anlamına gelen eski bir kelimeden 
türetilmiştir, Karhideliler için “prestij-yüz-yer-gurur” ilişkisiyle bağlantılı bir mesele olarak görülür ve çok önemlidir. Hislerini doğrudan belli etmeme temelinde, duygularla ifadeler arasına bir dolayım koyma ihtiyacından kaynaklanan şifgretor, Ai'ye göre tercüme edilemez bir konudur ve esasında toplumsal otorite ile ilgilidir. Tam da bu şifgretor konusu yüzünden Ai çoğu zaman insanların yüzlerini okuyamaz, ne demek istediklerini de anlamaz ve bu sebeple derin bir yalnızlık hisseder; "bir kedinin yüzü okunabilir mi, bir ayıbalığının, bir susamurunun?" (Le Guin, 2010: 26) diyerek durumu raporunda izah etmeye çalışır. Şifgretor aynı zamanda sosyal kuralları ve protokol nezaket setlerini de ifade eder. Ai'nin uzunca bir zaman çözemediği şey de zaten bu ortak kodlardır. Romanda süregiden tüm yanlış anlamaların sebebi Ai tarafından kesin bir cinsiyetin yokluğuna bağlanır, ona göre salt bu yüzden Gethenliler ile arasında ortak bir dil de kurulamıyordur. Ai kendisinin akıl yürütme biçimine uymadığı için iki yıldır Gethen'de yaşamasına rağmen olaylara, hayata "onların omuzlarından bakamaz", içsel bir anlama hissi yaşayamaz ve kendi yaşam dünyasına yapmaya çalıştı̆̆ çeviriler bir türlü tutmaz. Ai’nin bu husustaki esas sorunu androjenliği içselleştirememiş olmasıdır, bunun bir göstergesi olarak da şifgretorlarını çözemez.

Romanda olay örgüsünü başlatan moment elçinin, siyasi sebeplerden ötürü informantı tarafından terk edilmesidir. İnformantını kaybeden $\mathrm{Ai}$, toplumu tanıyarak bir şekilde kendi yolunu bulabilmek ve nihayetinde de amacını gerçekleştirebilmek için Gethen halkı ve kurumlarıyla iki yıldır kurmadığı biçimde bir ilişki kurmaya başlar. Ai’nin bu hususta toplumu anlamak ve bilgi toplamak için ilk yöneldiği yer, Handdara dininin inzivadaki müritlerinden oluşan “öndeyiciler” adında bir grup olur. Ai’nin hemen dine yönelmesi etnografi açısından da anlamlıdır. Zira dinin temel ontolojik önemini Eliade de (2016: 36) "kutsal" ve "profan" ayrımında, kutsalın tezahürünün bir referans noktası oluşturarak ontolojik olarak dünyayı kurmasından hareketle ortaya koymuştu. Dolayısıyla topluluğa içkin anlamların yakalanabileceği bir ortam olarak din, etnografik anlamda da hayli değerli bir inceleme alanıdır. Burada ethos ile ilişkili ikinci önemli kavram olan "nusuth" karşımıza çıkar. Ai bu kavramla, Karhidelilerin Handdara dini vesilesiyle tanışır. Nusuth kelimesi bir nevi bir dünya görüşünü temsil eder; "Handdara'nın her anlama gelen, muğlak olumsuzu"dur (Le Guin, 2010: 66) ve Ai bu kelimeyi kendi diline "fark etmez" olarak çevirir:

“İçe dönük bir yaşamdı, kendine yeterli, durgun Handdaratalar»ın değer verdiği kendine özgü «cehalet» ilkesi ve eylemsizlik ya da müdahale etmeme kuralına uygun bir yaşamdı. Bu kural (ki bunun en iyi ifadesi «fark etmez» diye çevirmek zorunda kaldığım, tam karşılığı olmayan nusuth sözüdür) bu kültün temeli ve ben de onu anlamış görünmeye çalışmıyorum. (...) Bu ülkenin siyasetinin, geçit alaylarının, tutkularının altında eski bir karanlık, Handdara'nın edilgin, anarşik, suskun, doğurgan karanlığı yatıyor" (Le Guin, 2010: 60-61).

Ai dinî ethosa yaklaştıkça toplumu daha iyi anladığını fark eder. Dinsel ontolojiyi keşfettikçe siyasette, ritüelde ya da gündelik hayatta gördüklerini içsel bir bakışla, topluluğa göründüğü şekliyle anlamlandırmaya başlar. Cehaletin de önemli bir kavram olduğunu keşfeden Ai, bunu eylemsizlik ve nusuth ile beraber okumak gerektiğini ayırt eder; "Cahil, Handdara anlamında, soyutlamaları reddetmek, nesnenin kendisine sıkı sıkı yapışmak 
anlamına gelir.” (Le Guin, 2010: 180). Ai'nin bu ilk informantsız deneyiminde hâlâ tam olarak oradaki hayata topluluğunun omuzlarının üstünden bakamadığını ve tavırları dişi ve erkek olarak düalist bir bakışla okumaya yöneldiğini görürüz.

Ancak burada dikkat çekilmesi gereken başka bir önemli nokta da Gethen'in iki ülkesi yani Karhide ve Orgoreyn arasındaki karşıtlıktır. Karhide'nin Handdara dininden, bir fikir ayrılığıyla ortaya çıkan Yomesh, Orgoreyn' in dinidir. Bu da iki toplumun farklı yaşam pratikleri sergilemesindeki ana ayrımdır. Buradan hareketle Gethen gezegeninde, androjenliğe dair iki farklı yaşanış biçiminin ortaya çıktığını söyleyebiliriz. Bu ayrım "kültürün getirdikleri” ile "doğanın getirdikleri” şeklinde bir okumaya da tabi tutulabilir. Orgoreyn'de Karhide'den farklı bir siyasal yapı ve dinsel örgütlenme mevcuttur. Terra- Gethen arasındaki temel fark cinsiyet üzerinden ilerlerken, Karhide ile Orgoreyn arasındaki ise dindir. Handdara daha ziyade bir denge felsefesini temsil ederken Yomesh, dengeleri reddeden monist bir görüşe sahiptir. Burada dine, hayatı tecrübe etmedeki temel ethosu kuran bir işlev yüklendiğini söyleyebiliriz. Ai Orgoreyn'de âdetlerin Karhide'den farklı olduğunu gözlemler.

Hepsi şifgretor ya da nusuth kadar derinlikli olmasa da metin, ethos yakalamalarıla doludur. Örneğin Karhide halkı pek okumayan, duymayı görmeden üstün tutan bir toplumdur. Cinsellikle ilgili konuları rahatça konuşabilirler, kahkahada nasıl utanılacak bir şeyler bulmuyorlarsa gözyaşları aktığında da utanmazlar, Ai Karhidelilerin kolayca ağlayıverdiklerini gözlemler. Dillerinde savaş kelimesi olmayan bu insanların yabancılara, düşman ya da işgalci gibi bakmadığını daha çok onları ağırlanması gereken konuklar olarak gördüklerini söyler. Kültürel değişim hızlarının çok yavaş olduğuna ve önsezilerini eğitebildiklerine dikkat çeker. Ketumluklarının ima ettiklerini ise şöyle değerlendirir Ai: “Karhide'de gizlilik büyük ölçüde bir hassasiyet meselesidir. Kabullenilen ve anlaşılan bir suskunluktur; soruların atlanıp geçilmesidir ama cevapların atlanıp geçilmesi değildir" (Le Guin, 2010: 239). Tez canlılığın Karhide'de işe yaramadığını belirten Ai onları, ağırkanlı değil ama inatçı ve sabırlı insanlar olarak görür, bir gündelik hayat betimlemesiyle iç içe geçirerek de bu husustaki ethoslarını yakalar:

"Ne kadar kalabalık olsa da ulaşım saatte ortalama 25 mil (Terra mili) hızla aksamadan devam eder, Gethenliler araçlarının daha hızlı gitmesini sağlayabilirler ama yapmazlar bunu. Nedeni sorulduğunda da "Neden?" diye yanıt verirler (...) Daima Bir Yılı’nda yaşayan Kış halkı içinse ilerleme, mevcudiyet kadar önemli değildir” (Le Guin, 2010: 53-54).

Burada da gördüğümüz üzere, Ai’nin bu gezegendeki gündelik hayat aktarımlarına dikkatli baktığımızda, androjenliğin yanı sıra ekolojik ilişkilerin de dikkat çekici olduğunu görürüz. Yeme içme düzenleri, besinleri, ulaşım için kullandıkları taşıtlar, mimari yapıları ve dili çevre şartlarıyla doğrudan ilişkilendirerek aktarılır.

“Karhideliler günde dört öğün yemek yerler (...) Kış’ta eti yenen büyük hayvanlar ve süt, tereyağı, peynir gibi memeli ürünleri yok: Yüksek proteinli, yüksek karbonhidratlı yiyecekler sadece çeşitli yumurtalar, balıklar, kabuklu yemişler ve Hain türü tahıllar. Zorlu bir iklim için düşük bir diyet, bu yüzden sık sık yakıt almak gerekiyor" (Le Guin, 2010: 22). 
Burada iklim koşullarına uyum sağlama, temel bir parametre olarak karşımıza çıkar. Ai Orgoreyn'in başkenti ve Gethen gezegenin en büyük şehri olan Mişnori’ye gittiğinde ilk gözüne çarpan şey çevre ve yaşamın uyumudur:

"Güz yağmurları arasındaki soluk gün 1şığında tuhaf görünüşlü bir şehirdi: Çok yüksekte az sayıda dar pencereleri olan binaları, kalabalıkların ufacık göründüğü geniş caddeleri, tuhaf biçimde yüksek direklere yerleştirilmiş sokak lambaları, dua etmek için açılmış eller gibi eğimli çatıları, yerden on sekiz feet yüksekte bulunan evlerden büyük ve işe yaramaz kitap rafları gibi uzanan balkonları ile günışığında orantısız, grotesk bir şehir. Gün 1şı̆̆ı için inşa edilmemişti. Kış için inşa edilmişti” (Le Guin, 2010: 104).

Rer denilen bir yerleşim bölgesini de yine insanların hava koşullarına nasıl mimari tepkiler verdikleri üzerinden betimler:

"Rer'de hiç cadde yok. Kapalı, tünel benzeri, yazları içinde veya üzerinde, nasıl isterseniz gidebileceğiniz yollar var. Ocaklar, evler ve adalar her yere serpiştirilmiş, dağınık, karışık, apansız ihtişam doğuran bir kargaşa içinde (...) Taş tünelleri kullanıyor ya da karın içinde geçici tüneller açıyorlar. Karlar evlerin neredeyse çatılarına dek ulaşıyor ve kış için çatı pencereleri gibi saçakların hemen altında, hatta damlarda kapılar açıyorlar" (Le Guin, 2010: 56).

Buradaki gibi çevre ile uyumlu bir hayat sürme ve yaşamın her alanında çevreyle intibak hali hususunda dil de ön plana çıkan temalar arasındadır. Soğuk hava şartlarının hüküm sürdüğü Gethen gezegeninin iklim koşullarının, gezegenin diline yansıdığını görürüz. Bugün için dilsel determinizm yaptıklarından dolayı eleştirilen ancak dilin göreliliğini ortaya koymaya çalışan Sapir ve Worf hipotezinin (1929) Inuit dili için söylediklerinin adeta bir uyarlaması olarak okunabilecek bu tespitler, Ai’ye göre yaşam koşullarının birer yansımasıdır:

"Yağan kar, yeni yağmış kar; çok önceden yağmış kar; yağmurla sulanmış kar; sulanıp donmuş kar (...) karın çeşitli türleri, aşamaları, evreleri için tam altmış iki kelime saymıştım; yağmış kar için yani. Kar yağışı çeşitleri için bir dizi başka kelime daha var; buz için de ayrı bir dizi; 1sı menzilini, rüzgârın esme gücünü, yağış türünü belirten yirmi küsur kelimelik bir başka dizi” (Le Guin, 2010: 147).

Öte yandan romanın sonuna eklenen ve olay örgüsünden bağımsız bölümde ise Gethenlilerin zamanı nasıl sınıflandırdıklarını anlatan bir takvim ve saat çevirisi bulunur. $\mathrm{Bu}$ da yine bahsi geçtiği üzere tıpkı din gibi ontolojik bir kategorizasyona işaret ettiğinden etnografik açıdan anlamlıdır.

Ethos ve gündelik hayat tasvirleri daha çok tecrübî bir çıkarıma karşılık gelirken yoğun betimlemeler ise, o ana özgü olayların ham bir bilgi nesnesi olarak detaylı bir şekilde aktarılmasıdır. Bu hususta Ai'nin “öndeyicilerle” yaşadığı tecrübe roman için özellikle ayrı bir yerde durur. Yukarıda da bahsi geçtiği gibi Ai informantsız kalınca, tek başına bilgi toplamak için ilk önce Handdara inzivasına yönelir. Burada, gelecekte olacaklara dair "öndeyi”de bulunan bir grup münzevi “öndeyici” yaşamaktadır. Öndeyilerini de kendilerine sorulacak bir soru üzerine düzenledikleri ritüelin sonunda dile getiriler. Ai "geleceği görme" fenomeninin 
farklı coğrafyalarda, farklı inançlardaki tezahürlerini de hesaba katarak kültürlerarası bir şekilde düşünür: "İnsanlığın tüm mekânlarında önceden görmeye dair efsaneler yaygındır. Tanrılar konuşur, ruhlar konuşur, bilgisayarlar konuşur. Falların muğlaklığı veya istatistiki olasılık bir sürü kaçamak sağlar ve tutarsızlıklar da iman ile halledilir. Gene de bu efsaneler araştırmaya değer gibi geliyordu bana" (Le Guin, 2010: 57). Öndeyicilerden biri, Ai’nin öndeyi pratiklerine dair bilgi elde etmek istediği için orada olduğunu öğrendiğinde etnografik anlamda da metodolojik öneme sahip bir soru yöneltir; ritüeli sadece gözlemlemek mi istiyordur yoksa katılmak mı? Bunun üzerine Ai de "Gethen dünyası beş yıl içinde Ekumen'e üye olacak mı?” sorusuyla ritüele katılır ve böylece katılımlı gözlemde daha derinlere iner. Bu deneyimini de metinde yoğun betimlemeler şeklinde anlatır.

Teknolojide diğer gezegenlerden geri olmaları, hiçbir şekilde provoke olup savaş çıkarmamaları, ekolojilerine uygun bir hayatı yaşamaları, yılın belli dönemlerinde "kızgınlığa girerek" üremeleri ve her daim kadınsılığın kuşatması altında olmasıyla bu alternatif insanlar Ai'nin gözünden, doğaya daha yakın "animalistik" bir yaşam formu şeklinde temsil edilmektedir. Öndeyi ritüelinin Ai için bir başka önemi de aslında gerçek manada ilk kez "halka karışıyor" oluşudur. Bu tecrübeden önce informantının güvenli alanından hiç çıkmamış, yerli halk ile uzaktan bir ilişki yürütmeye çalışmıştır. Ancak bu tecrübeden sonra, gezegenin bir ülkesinden başka bir ülkesine giderek artık katılımlı gözlemi yoğun bir şekilde deneyimleyecek ve tıpkı bir etnograf gibi bu tecrübelerini yazıya geçirecektir.

\section{Etnografin tecrübesi}

Farklı bir yaşam pratiğinin içinde araştırma yapan etnografın alandaki belki de ilk hissiyatı, doğal olarak yabancılıktır. Ai de romanda bu tarz duygularını çokça metne aktarır. Tam olarak anlayamadığı bir toplumda yaşadığı yalnızlıktan bahsederken zaman zaman kendi yaşamına dair şeyleri de, yaklaşımlarını da manasız bulur. Henüz dile ve davranış pratiklerine tam manasıyla aşina olamadığı için hep sınırda hisseder kendini: "Havadan sudan konuşmaya çalışıyordum (...) söylediğim her şeyin çift anlamı varmış gibi görünüyordu (...) pek az yabancı benim kadar yabancıdır" (Le Guin, 2010: 21). Etnografik alana araştırmasının başlarında alanda karşılaşan taraflar, farklı saiklerle de olsa hemen her zaman dikkatli olmaya kendilerini mecbur hissederler. Bir yanda yakaladığı ilişkiyi kaybetmekten korkarak bir hata yapmaktan her daim kaçınan araştırmacı, sözleri ve davranışları konusunda hep ihtiyatlı olmak zorunda kalırken diğer yanda informantlar da "yanlış" bir izlenim bırakacakları ve “doğru” temsil edilemeyecekleri kaygısıyla, en azından tanışana kadar, teyakkuz halindedirler. Romanda Ai, kendi yalnızlığının ve yabancılık duygusunun yanı sıra toplum içinde de her daim dikkat çeken kişidir; fiziksel olarak farklıdır, yabancıdır. Gethen normundan biraz daha uzundur, esmerdir, cinsel olarak kural dışı bir şekilde cinsiyetlidir, aksanlıdır. Kalabalık içinde sahip olduğu bu farklılık daha da belirginleşir ve zamanla kendisini daha da rahatsız etmeye başlar. Ai’nin bir yalnızlık duygusuna kapıldığı anda günlüğüne aldığı notlar ilk bakışta, bu hususta "adı çıktığı” için Malinowski'nin günlüklerini anımsatsa da bunların alanda uzun zaman geçiren hemen herkesin paylaştığı bir his olduğunu söylemek iddialı olmayacaktır: 
"Birden yalnızlık duygusuna, sıla özlemine kapıldım. İki yılımı bu lanet olası gezegende geçirmiştim (...) Ve hep kendi başıma, yabancı ve yalnız, güvenecek kimsem olmadan” (Le Guin, 2010: 118).

Şimdiye kadar Ai’nin yabancılık hissi, uzamsal olarak yer değiştirmek ya da alışkın olduğu pratiklerden uzak olmak bağlamında ele alınmış olsa da bu duygunun bir diğer boyutu da zamanla ilgilidir. Ai Gethenliler ile kendini aynı zaman düzleminde görmez. Bu bağlamda Fabian'ın (1999: 54) antropolojik söylemin nesnesini mümkün kılma tarzının, tam da toplulukları bu şekilde bir zamansal bir mesafeye oturtmasından kaynaklandığına dikkat çektiğgini hatırlayalım. Antropolojinin Batı dışı toplumlara farklı bir zaman tahsis etme tutumunu Fabian "zamandaşlığın inkârı" olarak kavramsallaştırır ve buradaki akıl yürütmeye uygun bir biçimde Ai de Gethenlilere baktığında kendini bir zaman yolculuğunda görmektedir. Öndeyicilerin Dokumacısı Faxe’ye bakarken Ai’nin aklından geçenler şunlardır: “bana baktığında on üç bin yıllık bir gelenekten bakıyordu; öylesine eski, öylesine köklü, bir insana vahşi bir hayvanın özbilinçsizliğini, yetkesini, tamlığını verecek denli bütünsel ve tutarlı bir düşünce ve hayat tarzı bakıyordu size" (Le Guin, 2010: 69). Hem zamansal ve uzamsal mesafeden hem de alışkın olmadığı sosyal ve biyolojik pratiklerden dolayı kendini yabancı hisseden Ai’nin bu duygusunun karşılıklılığı da metinde vurgulanır. Gören olduğu kadar görünen, yabancıladığı kadar yabancılanan biridir. Gethenlilerin biyolojisine göre sürekli "kemmerde" olan Ai, topluma göre "cinsel sapık"tır. Yabancılık hissinden bir nebze de olsa Ai’yi uzaklaştıran kişi, yakın ilişki kurduğu informantı, aynı zamanda "Kralın Kulağı", Estraven'dir. Hem araştırmacı informant iliş̧isini hem de Ai’nin davranışlarının nasıl algılandığını görmemiz açısından Estraven'in dilinden yazılmış bölümler bilhassa önemlidir. Zaman zaman aynı olayı bir Ai'nin bir de Estraven'in penceresinden kendi anlatımlarıyla okuruz. Böylece alanda cereyan eden olayların hiçbir zaman tek bir görünüme sahip olmadığını; araştırmacının da salt gören ya da bilen kişi olmadığını, bizatihi görünen ve bilinen olduğunu anlarız. Estraven ile Ai'nin yakınlığı, Estraven'in bir siyasetçi olarak Ekumene katılma fikrini desteklemesi dolayısıyla ilk başlarda sadece profesyonel bir menfaat ilişkisi olarak başlasa da zaman içinde dönüşerek devam eder. Olay örgüsünün hemen başlarında Estraven desteğini çektiğini söylediğinde Ai, alanda informantıyla problem yaşayan herkesin çok iyi bildiği o korkuyu yaşar: "Üşümüştüm, güvensizdim, ihanet duygusu, yalnızlık ve korku kaplamıştı içimi” (Le Guin, 2010: 30). İnformantı tarafından terk edilen Ai, o olmadan da işleri yürütebileceğine kendini ikna etmeyi dener. Önce hemen saray adabı üzerine aldığı notlara döner ve kendisinden önceki araştırmacıların Gethen psikolojisi ve adetleri üzerine gözlemlerini okuyarak infortmantsızlığa hazırlanmaya çalışır. İlkin Handdara inzivasına gittikten sonra başka seyahatler yapıp zamanını Gethen halklarını gerçekten tanımaya vakfeder. Ancak bir süre sonra kimi bazı siyasi güvensizliklerin sonucunda kendisini istihbarat servisi tarafından sorgulanırken bulur. Ai'nin bu duruma düşmesinde kendisini suçlu hisseden Estraven, Ai'yi buradan kaçırır ve illegal bir biçimde, canları pahasına Karhide’ye doğru yolculuğa çıkarlar. Buzun üzerinde, yalnızca ikisinin olduğu, toplumsallıktan yalıtılmış bir şekilde haftalarca süren bu yolculuk, ikilinin ilişkisini başka bir boyuta taşır. İlkin Estraven baş informant konumunu geri kazanır. Ancak öncekinden farklı olarak bu sefer gerçek manada 
tanışırlar; birbirlerinin akıl yürütmelerini ve hislerini öğrenirler, "bilen" "bilinen" arasında olduğu varsayılan ilişki dönüşür. Bu Ai için Gethen'e dair her şeyin manasını değiştirecek bir deneyim olur. Anlamlarla yüklenmemiş bir uzamda, herhangi bir insan pratiğinden uzaktadırlar. Sosyal olarak ne Terra'dadırlar ne de Gethen'de; haftalarca üzerinde yaşadıkları mekân dağlar, buzlardır. Dolayısıyla birisinden birisinin baskın olabileceği bir kültür evreni içinde değillerdir. Ama kendi pratiklerinde taşıdıkları iki dünya, buzun üstünde bir aradadır; eşit, yabancı ve yalnızdırlar. İlişkilerinin bu yeni biçiminde paylaşımları giderek artar ve geldikleri noktada artık cinselliklerini de paylaştıklarına dair romanda bir ima da bulunur. $\mathrm{Bu}$ hususta, etnografın tecrübesi bağlamında alandaki bu tip hikâyelerin konu edildiği ve literatürde hayli ses getiren Tabu: Antropolojik Alan Çalışmasında Seks, Kimlik ve Erotik Öznellik (Kulick ve Willson, 2000) kitabını da zikrederek geçelim.

Öte yandan Ai ile Estraven'in buz üzerindeki tecrübeleriyle dönüşen etnograf-informant ilişkisi, bir tür alış-veriş haline gelir. Örneğin Ai, yüksek teknolojiye sahip olan Terralıların kullandığı zihin konuşmasını Estraven'e öğretir. Aslında Ekumen tarafından bu bilginin yerlilere öğretilmesi yasaklanmıştır. Ai, Estraven ile ilişkilerinin geldiği noktada kuralları artık önemsemez ve zihin konuşması yöntemini Estraven'e öğretir. "Yerliler ile paylaşılabilecek bilgi" konusu, cinsel ilişki ile üreme arasındaki bağlantıyı bilmemeleri hususunda Malinowski’nin (1992) Melanezya yerlileriyle yaşadığı çelişkiyi anımsatacaktır. O da neticede, yerlilere bu konuda "doğru" bir bilgi dikte ettiğinde, kendi anlamlandırmaları üzerine kurulmuş olan bütün sosyal düzenlerini değiştirebileceğini keşfettiğinden, yıkıcı bir etki yaratmamak için sahip olduğu "bilimsel bilgiyi” çoğunlukla kendine saklamayı tercih edecektir.

Aynı zamanda Ai, kendi başına ettiği seyahatlerden ve gözlemlerinden bilgi iktidar ilişkisine dair yeni şeyler öğrenir. İkna etmek için halkı tanımak, onun için de sahanın çeşitli yerlerinde gezip dolaşmak, gündelik hayatına katılmak gerekiyordur. Bilmenin, manipüle etmenin ön koşulu olduğunu kavrayan Ai, halkı da yekpare bir yapı olarak görmenin çıkmazlarını tecrübe eder. Kendisi için yeni olan bu yaşam dünyasına dair tüm ayrımları yaşayarak kavrayan ve artık hayata onların omuzları üzerinden bakmayı öğrenen hatta bunu içselleştiren Ai, romanın sonunda kendisini Gethen'den almaya gelen insanlara başka bir gözle bakacak, kendi türünü gördüğünde yadırgayacaktır.

Diğer taraftan Ai'nin, Gethenlilere gezegenlerine neden tek geldiğini açıkladığı şu cümleler, etnografik yöntemin uygulanış biçimi ve tecrübesi açısından hayli önemli bir mesele olarak karşımıza çıkar:

“Tek başıma dünyanızı değiştiremem. Ama o beni değiştirebilir. Tek başıma bir ilişki kurmayı başarırsam bu kişisellikten yoksun ve sadece politik bir ilişki olmaz; bireysel ve kişisel bir ilişki olur (...) Ben ve Sen” (Le Guin, 2010: 218).

$\mathrm{Bu}$ sözler aynı zamanda etnografik yönteme dair bir iddiayı da içinde barındırır. Etnografik saha araştırmasına, en fazla kişiye ulaşılabilmesi kaygısıyla kalabalık bir şekilde yapılan anketlerin aksine çoğunlukla tek kişi gidilir ve sahada az kişiyle, derinlemesine kurulan ilişkiler üzerinden işler. Ai'nin bu ifadesi yöntem ile tecrübe arasında bir köprü kurar. Alan tecrübesi, her zaman dönüşüme dair radikal bir potansiyel taşır. Hatta tam da 
bu sebeple varlığı olanaklı hale gelir. Etnografik metin de aslında en temelde, etnografin alandaki karşılaşma tecrübesini, yani oradaki hayatını, anlatıya dönüştürmesinden doğar. Diğer bir ifadeyle, etnografiyi mümkün kılacak kurucu etkiyi başlatan unsur, bir yerlerdeki "gündelik hayatın olağan-içi ve olağan-dışı, uzak ve bildik görünebilen hallerini; sahnenin farklı noktalarından farklı zamanlarda bakıldığında hem içinde hem de kenarında duran etnografın olan biteni nasıl tecrübe ettiğini” anlatmasıdır (Yazıcı Yakın, 2019: 28).

\section{Sonuc}

Romanda elçi Ai’nin Ekumen'deki işi “gezicilik” olarak adlandırılır; kendi dillerindeki manası "uzaklara uzanma"dır ve bu uzanma sırasında anlamlandırmak için aradıkları şey de rasyonel simgelerden ziyade bir bütünselliğin sezgisel algısının yakalanacağı yer olan metaforlardır. Bu çalışmada ise yapmak istediğim şey gezicilik ile etnograflığı örtüştürerek, araştıran ile araştırılanın karşılaşmasını metne dönüştüren Karanlığın Sol Eli romanındaki elçinin tecrübelerini ifade ediş biçimini, etnografinin anlatı yapısı üzerinden tartışmaya açmaktı. Etnografinin bilimsel iddialarından uzak, farklı bir metin tipi üzerinden metinlerarası bir perspektifle etnografinin kendini yazıya geçirmesi konusuna 1şı tutarken etnografik metinselleştirmeyi oluşturan örüntülerin izini sürdüm. Şüphesiz aynı romanı okuyan bir başka kişi de etnografik olan ya da olmayan başka unsurlar görebilir, farklı kavramsallaştırmalar geliştirebilir ya da ortaya koyulan bu perspektiften hareketle başka metinleri de burada açılan yoldan geçerek okuyabilir. Bu çalışmada da her metnin potansiyel olarak başka okumalara tabi tutulabileceğinin farkında olarak "metnin çok değerliliğii” üzerinden bir bakış geliştirmeye çalıştım. Burada ortaya koyulan özgün bakış vesilesiyle çalışmanın, "bir metin olarak etnografi” tartışmalarına mütevazı bir katkı yapmaya aday olduğunu düşünüyorum.

\section{Not}

1 İnformant, sahada tanışılan ve bilgi alınan kişi anlamına gelen antropolojik bir kavramdır. Kelimeyi Türkçeye "bilgi veren kişi”, "bilgilendirici”, "haber kaynağı” ya da "muhbir” olarak çevirmek mümkün olsa da etnograf ile ilişkisini işaret etmekte yetersiz kaldıklarını düşündüğüm için metinde çevirmeden kullanmayı tercih ettim.

\section{Kaynakça}

Bakhtin, M. (1982). The dialogic imagination. (M. Holquist, Ed.) Austin: University of Texas. Barthes, R. (2013). Dilin çalışma sesi. (A. Ece, N.K. Sevil ve E. Gökteke, Çev.) İstanbul: YKY.

Barrow, C. and Barrow D. (1987). The left hand of darkness: Feminism for men. Mosaic: An Interdisciplinary Critical Journal, 20,( 1), 83-96.

Clifford, J. (1986a). Partial truths. Writing Culture: The Poetics and Politics of Ethnography, Clifford, J. and Marcus. (G. E., Ed) Los Angeles: University of California.

Clifford, J. (1986b). On ethographic allegory. Writing Culture: The Poetics and Politics of Ethnography, Clifford, J. and Marcus. (G. E. Ed.) Los Angeles: University of California. 
Chatman, S. (2009). Öykü ve söylem: Filmde ve kurmacada anlatı yapısı. (Ö. Yaren, Çev.) Ankara: De Ki.

Eliade, M. (2016). Okültizm, büyücülük ve kültürel modular. (C. Soydemir, Çev.) Ankara: Doğu Batı.

Fabian, J. (1999). Zaman ve öteki: Antropoloji nesnesini nasıl oluşturur? (S. Budak, Çev.) Ankara: Bilim ve Sanat.

Fayad, M. (1997). Aliens, androgynes, and anthropology: Le Guin's critique of representation in the left hand of darkness. Mosaic: An Interdisciplinary Critical Journal, 30, (3), 59-73.

Foucault, M. (1981). What is an author? Theories of authorship. (J. Caughie, Ed.) London: Routledge, 282-291.

Foucault, M. (2006). Deliliğin tarihi. (M. A. Kılıçbay, Çev.) Ankara: İmge.

Geertz, C. (2010). Kültürlerin yorumlanması. (H. Gür, Çev.) Ankara: Dost.

Heidegger, M. (2011). Varlık ve zaman. (K. Ökten, Çev.) İstanbul: Agora.

Lake, D. J. (1981). Le Guin's twofold vision: Contrary image-sets in the left hand of darkness. Science Fiction Studies, 8, (2), 156-164.

Le Guin, U. (2010). Karanlığın sol eli. (Ü. Altuğ, Çev.) İstanbul: Ayrıntı.

Malinowski, B. (1989). A diary in the strict sense of the term, London: The Athlone.

Malinowski, B. (1992). Vahşilerin cinsel yaşamı. (S. Özkal, Çev.) İstanbul: Kabalcı.

Pearson, W. G. (2007). Postcolonialism/s, gender/s, sexuality/ies and the legacy of the left hand of darkness: Gwyneth Jones's Aleutians talk back, The Yearbook of English Studies,37, (2), 182-196.

Platon, (2012). Şölen-dostluk. (S. Eyüboğlu ve A. Erhat, Çev.) İstanbul: Türkiye İş Bankası.

Scholte, B. (1987). The literary turn in contemporary anthropology. Critique of Anthropology, 7, (1), 33-47.

Yazıcı Yakın, A. (2019). Alelade şeyleri anlatmak. Etnografi olağan-içi tecrübe. (A. Yazıcı Yakın ve M. Kükrer, Ed) Ankara: Doğu Bat1.

Walker, J. M. (1979). Myth, exchange and history in the left hand of darkness. Science Fiction Studies, 6, (2), 180-189.

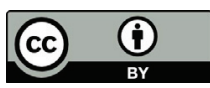

$\mathrm{Bu}$ eser Creative Commons Atıf 4.0 Uluslararası Lisansı ile lisanslanmıştır.

(This work is licensed under a Creative Commons Attribution 4.0 International License). 